УДК 94(470.40)

ББК 63.3(29)

\title{
К ВОПРОСУ О ТЕРРИТОРИАЛЬНОЙ ЛОКАЛИЗАЦИИ АДМИНИСТРА- ТИВНОГО ЦЕНТРА ЧУВАШСКОЙ (ЗЮРЕЙСКОЙ) ДАРУГИ
}

\author{
(C) 2020 г. P.Р. Салихов, Р.Р. Исхаков
}

Одним из актуальных вопросов средневековой истории Среднего Поволжья является определение места центров административно-территориальных областей (даруг) в социально-политической и военной системе Казанского ханства, а также их преемственности с одноименными населенными пунктами Казанского края периода Московского господства. Весьма важной проблемой остается их территориальная локализация и проведение комплексных историко-археологических исследований. В рамках данной статьи, на основе имеющейся на сегодняшний день эмпирической базы, предпринимается попытка определения места расположения центра Чувашской (Зюрейской) даруги.

Ключевые слова: средневековье, Среднее Поволжье, Казанское ханство, городок, даруги, Старые Зюри, административно-территориальное деление.

\section{ON THE ISSUE OF TERRITORIAL LOCALIZATION OF THE ADMINISTRATIVE CENTER OF THE CHUVASH (ZUREYSKAYA) DARUGA}

\section{R.R. Salikhov, R.R. Iskhakov}

One of the topical issues in the medieval history of the Middle Volga region is the determination of the place of the centers of administrative-territorial regions (daruga) in the socio-political and military system of the Kazan Khanate, as well as their continuity with the settlements of the same name in the Kazan Territory during the period of Moscow domination. Their territorial localization and the conduct of comprehensive historical and archaeological research remain a very important problem. Within the framework of this article, on the basis of the empirical base available today, an attempt is made to determine the location of the center of the Chuvash (Zureyskaya) Daruga.

Keywords: Middle Ages, Middle Volga Region, Kazan Khanate, Zureysky town, daruga, Starye Zuri, administrative-territorial division.

Вопрос о территориальной локализации центра одной из административно-территориальных областей Казанского ханства, а впоследствии Казанского наместничества, известная по русским летописям и писцовым описаниям XVI-XVII в., как Чувашская (Чювашская) и Зюрейская дорога (даруга) был поднят в работах казанских историков второй половины XIX в. Исходя из преемственности названий, исследователи были склоны связывать Зюрейский городок с одноименной деревней, расположенной на западной оконечности Мамадышского уезда Казанской губернии. Важным аргументом в пользу данной гипотезы стало выявление на территории этой татарской деревни (Старые Зюри) крупного средневекового городища. В 1828 г. на страницах «Казанского вестника» (№46) вышла небольшая заметка, в которой в частности отмечалось, «что в Мамадышском уезде около дер. Старые Зюри есть остатки рва, концы которого примыкают к р. Меше, на берегу реки земляная насыпь, на которой поставлен камень довольной величины с высеченными... арабскими буквами. По сим приметам полагают, что там был в древности столичный город какого то хана» (Шпилевский, 1877 , с. 401). Но уже во второй половине XIX в., приезжавшие в деревню ученые были вынуждены констатировать, что найти и исследовать этот археологический памятник не представляется возможным в связи со смещением русла р. Меша. С.М. Шпилевский посетивший этот край в начале 1870-х гг. отметил, что «время сгладило с камня буквы, а насыпь обратило в дно реки» (Шпилевский, 1877 , с. 401). Интересно и другое наблюдение казанского историка: «вероятнее, кажется назвать сие место городищем или мольбищем, ибо по слухам татары окрестных селений съезжаются туда и поныне в известное время для моления» (Шпилевский, 1877, с. 401). Из этого наблюдения, наряду с фактом разрушения городища, можно почерпнуть инфор- 
мацию о сохранении у местного населения исторической памяти об этом месте. Данные C.M. Шпилевского подтверждают и ученые, побывавшие здесь в последующее время. Известный казанский топонимист и этнограф И.А. Износков также пишет, о наличии возле Старые Зюри «древнего городища» и сохранении среди жителей предания о том, что здесь был город Зюри (Износков, 1895, с. 20).

В 1925 г. казанскому этнографу Н.И. Воробьеву, во время научной экспедиции по Мамадышскому кантону ТАССР представилась возможность посетить дер. Старые Зюри. По его мнению, территория селения представляла большой интерес в плане изучения археологических памятников средневековой Татарии. Ученый отметил, что «в Зюри, как и недалеко от нее расположенной дер. Казаклар имеются многочисленные предания, указываются многочисленные урочища, связанные с историей болгарских времен. Детальное обследование этого района представляет важную задачу местной археологии» (Воробьев, 1929, с. 12).

Комплексные археологические исследования в окрестностях дер. Старые Зюри начинают проводиться с 1950-х гг. Р.Г. Фахрутдиновым. Возле дер. Большие Тюлязи в 1955 г. был собран подъемный материал на площади 250 кв. м, состоящий из болгарской керамики позднего облика (Археологическая карта, 1981, с. 108). В этом же году ученым к востоку от с. Мамалаево, на распаханном краю надлуговой террасы были проведены раскопки, в результате которых было обнаружено селище датируемое «позднеболгарским» и «ханским» (временем существования Казанского ханства) периодом. Выявлены: культурные остатки и гончарная керамика красного, коричневого и серого цветов с лощением и орнаментом, ключ от цилиндрического замка с четырехугольным вырезом на круглой бородке (Археологическая карта, 1981, с. 109). Археологические раскопки проводились и на территории дер. Старые Зюри. По этому поводу в книге «Археологическая карта Татарской АССР. Предкамье» лаконично сказано: «Около села исследователями прошлого столетия отмечалось городище, рвы которого концами подходили к реке. Экспедицией ИЯЛИ 1955 г. городище не обнаружено. Поблизости находится татарское кладбище с надгробным камнем первой половины XVI столетия» (Археологическая карта, 1981, с. 108). В августе 2001 г. казанскими археологами на терри- тории современной дер. Старые Зюри были заложены 9 раскопов и шурфов (4-2, 6-2, 4-2, 3-1, 2-2, 2-2, 3-1, 2-1, 1-1 м.), которые зафиксировали культурные слои от 25 до 110 см. В ходе раскопок выявлена керамическая посуда, железные изделия, каменные находки, кости животных. Керамический материал был датирован XIV-XVI и XVII-XIX вв. Кроме того, в 2 км. от Старые Зюри, на правом берегу р. Меша в районе «скотомогильника» им были проведены разведочные работы, в ходе которых были собраны керамические и железные изделия относящиеся к XIII-XVI вв. (Бурханов, 2003, с.261).

Таким образом, в связи со смещением русла р. Меша и проживанием в районе городища сельского населения активно занимавшегося хозяйственной деятельностью способствовавшей разрушению этого археологического памятника, обследования и раскопки не позволили выявить полную картину возникновения и развития Зюрейского городка и его места в военно-политической и административной системе Казанского ханства. В связи с этим, для уточнения данного вопроса весьма перспективным является привлечение письменных источников и народного фольклора, в котором сохранилась многовековая историческая память народа. В фондах Тюлячинского краеведческого музея хранится татарская рукопись, в которой приводиться легенда, что основателем деревни Старые Зюри был некий Зюри хан, перенесший впоследствии свою резиденцию в Казань (Галлям, Хисматуллин, 2016, с. 229). С именем «Зюри хана» связан другой исторический памятник, обнаруженный в дер. Старые Зюри. На левом берегу Меши, на северной окраине селения, сохранилась могила и памятник (120-46-17 см.), известные в народе как «Могила дочери Зюри хана». Расшифровка надписи на надмогильном камне показывает, что здесь похоронен Әйлим Исмәгыйль ульл, скончавшийся в 922 г. по хиджре (1516 г.). Качество обработки камня свидетельствует, что покойный имел высокое происхождение, был представителем военнофеодального сословия или государственной бюрократии.

Эти исторические материалы дают возможность сделать некоторые выводы о возникновении Зюрейского городка. В познезолотордынский и ханский период рассматриваемый район активно заселяется тюрко-татарским населением, здесь появляются татарские населенные пункты, основанные выходцами из 
Закамья. Административным центром округи стал Зюрейский городок, располагавшийся на территории современной дер. Старые Зюри. Само её возникновение и название связывается с личностью и деятельностью, какого-то крупного феодала по имени Зюри хан. Необходимо отметить, что в данном случае титул «хан» зафиксированный в этом предании отражает специфику, характерную для многих татарских легенд и обозначает не верховного, а местного правителя (бий, князья и проч.) из числа высшей знати (Галлям, Хисматуллин, 2016, с. 229). Важным является информация о связи возникновения Зюрейского городка и истории Казани. Это может быть косвенным свидетельством того, что основание деревни совпала с периодом превращения Казани в крупный военно-административный центр, в хронологическом отношении совпадающий со временем падения значения Болгара в конце XIV - первой половине XV в.

Само расположение Зюрейского городка говорит о том, что поселение возникло не путем вольной колонизации и освоения татарским населением территории Заказанья как большинство других татарских деревень, a в результате целенаправленной деятельности государственной администрации или крупного феодала. В пользу этого предположения можно привести следующие аргументы: 1) природно-географическое расположение - поселение было основано в районе, где p. Меша образует естественный «полуостров». Такой рельеф, создавал благоприятные усло- вия для обороны укрепленного городка. Тогда еще довольно глубокая и полноводная Меша создавала естественное препятствие для неприятеля с трех сторон, значительно облегчая возможности защиты укрепления. Кроме того, большие пойменные плодородные участки луга вдоль берега позволяли развивать здесь сельское хозяйство и обеспечивать местное население продовольствием; 2) близость крупнейшего тракта соединявшего Казань с Закамьем и Приуральем. Необходимость контроля над такой важной транспортной артерией, по которой везлись товары и ясак из Приуралья и Сибири, способствовала возникновению вдоль нее пунктов, обеспечивавших торговые караваны охраной, ночлегом, пищей, а также дававшие возможность чиновникам собирать транспортные и торговые пошлины в пользу верховной власти. В этом отношении район Зюрейского городка как нельзя лучше подходил для этих целей.

Это позволят сделать вывод, что Зюрейский городок создавался как важный торговый узел на пути из Казани в Закамье и Зауралье. В период Казанского ханства он начинает играть важную роль в административной системе государства, наряду с Арском, Лаишевом, Мамадышем и Челнинским городком. Консолидируясь с мнением предшествующих исследователей (Мухамедьяров, 2012, с. 227-228; Әхмәтжанов, 2012, 36 б.), мы склоны считать, что в это время он приобретает статус политико-административного центра одной из даруг Казанского ханства.

\section{ЛИТЕРАТУРА} $211 \mathrm{c}$.

Археологическая карта Татарской АССР. Предкамье / Отв. ред. А.Х. Халиков. М.: Наука, 1981.

Бурханов А.А., Замалтдинов Р.P. Изучение средневековых памятников в Заказанье в 2001 году // Древности. / под общей ред. Б.Я. Ставитского. М.-Казань, 2003. С. 261.

Воробьев Н.И. О Болгаро-татарских надгробных камнях Мамадышского кантона ТССР // Материалы по охране, ремонту и реставрации памятников ТССР. Т. III. Казань: Полиграфшкола им. А.В. Луначарского, 1929. С. 11-14.

Галлям Р.Г., Хисматуллин Б.Р. Легенда о Зюри хане // Из истории и культуры народов Среднего Поволжья. 2016. №6. С. 225-231.

Износков И.А. Материалы для истории христианского просвещения инородцев Казанского края. Вып.3. М.: Тип. Снегиревой, 1895. 47 с.

Мухамедьяров Ш.Ф. Социально-экономический и государственный строй Казанского ханства (XV - первая половина XVI вв.). Казань: Изд-во «Ихлас»; Институт истории им. Ш. Марджани АН РТ, 2012. $276 \mathrm{c}$.

Шпилевский С.М. Древние города и другие булгарско-татарские памятники в Казанской губернии. Казань: Типография Казанского ун-та, 1877. 586 с.

Әхмәтжсанов М. Татар археографиясенә сәхифәләр. Тарих пәрдәләре күтәрелгәндә. Казан, 2012. 156 б. 


\section{Информация об авторах:}

Салихов Радик Римович, доктор исторических наук, Институт истории им. Ш. Марджани АН РТ (г. Казань, Россия); history@tataroved.ru

Исхаков Радик Равильевич, доктор исторических наук, Институт истории им. Ш. Марджани АН РТ (г. Казань, Россия); ishakovist@gmail.com

\section{REFERENCES}

Khalikov, A. Kh (ed.). 1981. Arkheologicheskaia karta Tatarskoi ASSR. Predkam'e (Archaeological Map of the Tatar ASSR. Cis-Kama River area). Moscow: "Nauka" Publ. (in Russian).

Burhanov, A. A., Zamaltdinov, R. R. 2003. In Stavitskiy, B. Ya.(ed.). Drevnosti. (Antuquie) Moscow, Kazan, "Gumanitarya" Publ. (in Russian).

Vorobev, N. I. 1929. In Materialy po okhrane, remontu i restavratsii pamiatnikov TSSR (Materials on the Protection, Repair, and Restoration of the Monuments in Tatarian Soviet Socialist Republic). Vol. III. Kazan: "Poligrafshkola im. A. V. Lunacharskogo" Publ., 11-14 (in Russian).

Gallyam, R. G., Hismatullin, B. R. 2016. In Iz istorii i kultury narodov Srednego Povolzhya (From History And Culture Of Peoples Of The Middle Volga Region) (6) 225-231.(in Russian).

Iznoskov, I. A. 1895. Materialy dlya istorii hristianskogo prosvesheniya inorodcev Kazanskogo kraya (Materials for the history of Christian enlightenment of foreigners of the Kazan region). Vol. 3. Moscow: A.I. Snegireva Publ., (in Russian).

Muhamedyarov, Sh. F. 2012. Socialno-ekonomicheskij i gosudarstvennyj stroj Kazanskogo hanstva (XVpervaya polovina XVI vv.). (Socio-economic and state system of the Kazan Khanate (XV - the first half of the XVI century)). Kazan: "Ihlas" Publ., Institute of History named after Sh. Mardzhani, Tatarstan Academy of Sciences (in Russian).

Shpilevskii, S. M. 1877. Drevnie goroda i drugie bolgarsko-tatarskie pamiatniki v Kazanskoi gubernii (Ancient Towns and Other Bulgar-Tatar Sites in the Kazan Province). Kazan: Typography of the Kazan University (in Russian).

Ahmetzanov, M. 2012. Tatar arheografiyasena sahifeler. Tarih pardelare kytarelgenda. (Pages from Tatar archaeography. Opening the curtain of history) Kazan (in Tatar).

\footnotetext{
About the Authors:

Salikhov Radik R., Doctor of Historical Sciences, Institute of History named after Sh. Mardzani of Tatarstan Academy of Sciences. Baturina Str., 7a, Kazan, 420111, Republic of Tatarstan, Russian Federation; history@tataroved.ru

Iskhakov Radik R., Doctor of Historical Sciences, Institute of History named after Sh. Mardzani of Tatarstan Academy of Sciences. Baturina Str., 7a, Kazan, 420111, Republic of Tatarstan, Russian Federation; ishakovist@gmail.com 